\title{
Slovensko špranja in sorodno
}

\author{
MetKa FuRLAN \\ ZRC SAZU, Novi trg 2, SI-1000 Ljubljana, \\ metka.furlan@zrc-sazu.si
}

SCN IV/2 [2011], 32-44

\begin{abstract}
Slovensko špránja 'razpoka' in hrvaško špränja 'trska' se izvaja iz psl. nomena actionis *čb-pörni (f.) 'cepljenje' prefigiranega glagola *čb-pör-ti, ki je bil sinonimen s psl. *pör-ti 'bosti, ločevati, cepiti, parati', prim. r. porótb, pórešb 'parati', sln. práti, pọ́rjem/pórjem 'parati, trgati'.
\end{abstract}

Slovenian špránja 'crack' and Croatian špränja 'wood chip' derive from the PSl. nomen actionis *čb-pörni (f.) 'splitting' from the prefixed verb *čb-pör-ti, which was synonymous with PSl. *pör-ti 'prick, separate, cleave, rip', cf. Rus. porótb, pórešb 'rip', Sln. práti, pọ́rjem/ pórjem 'rip, tear'.

Ključne besede: etimologija, besedotvorje, pomenoslovje, ekspresivna predpona

Keywords: etymology, word formation, semantics, expressive prefix

1 Etimološko ${ }^{1}$ raziskovanje slovanske leksike ima dandanes že častitljivo starost ne glede na to, ali za mejnik njenega postanka jemljemo prvo bolj obširno in sistematično delo Miklošičev Etymologisches Wörterbuch der slawischen Sprachen iz leta 1886 in pa morda katero od starejših prav tako pionirskih etimoloških del kot npr. Dobrovskega Entwurf zu einem allgemeinen Etymologikon der slawischen Sprachen (Praga, 1813). Od tedaj je večina slovanskih nacionalnih jezikov dobila svoj temeljni etimološki slovar ali pa se njihova izdelava približuje koncu. Ponekod so pobudo za izdelavo novih nacionalnih etimoloških slovarjev dale nove politične razmere. Vzporedno s to slovarsko aktivnostjo je na temo slovanske etimologije izšla težko obvladljiva množica etimoloških monografij in še večje število etimoloških člankov. V Rusiji in na Poljskem sta se sočasno, leta 1974, začela izdelovati dva praslovanska eti-

${ }^{1}$ Vsebina prispevka je bila v krajši verziji predstavljena 16. oktobra 2010 v Gospiću na VII. Skokovih etimološko-onomastičnih srečanjih. 
mološka slovarja, pri čemer je delo pri poljskem izgleda zastalo, ruskemu pa želimo uspešno nadaljevanje in čimprejšnji zaključek, saj tako delo slovanska etimologija zaradi njegove sintetičnosti in povezovalnosti nujno potrebuje, ker je na eni strani koristno za posamezne slovanske nacionalne etimologije, na drugi pa za druge indoevropske in seveda za indoevropsko etimologijo. Žal zaradi svoje nepopolnosti take vloge ne more imeti v letu 2008 izšli Etymological Dictionary of the Slavic Inherited Lexicon Nizozemca Ricka Derksena. Skorajda kot gobe po dežju so - zdi se - po Gluhakovem Hrvatskem etimološkom rječniku iz leta 1993 začeli izhajati enozvezkovni nacionalni etimološki slovarji za širšo edukativno rabo, ki zaradi želje po čim širši razumljivosti etimologijo podajajo sila poenostavljeno in s tem tudi pri jezikoslovcih neetimologih vzbujajo nerealen vtis, da so slovanske nacionalne etimologije bolj ali manj izčrpano delovno območje, o katerem ni mogoče pričakovati nič več bistveno novega. Če etimologija ne bi bila znanost, bi bil tak vtis lahko realen. Pa temu seveda ni tako. Če pustim ob strani najmlajšo in zato tudi etimološko najlažje razložljivo plast leksike, tj. vedno znova porajajoče se neologizme domačega in tujega izvora, se etimolog pred novimi raziskovalnimi izzivi takorekoč vsakodnevno znajde zaradi vedno bolj izpopolnjene evidence slovanskega nacionalnega dialektičnega gradiva pa tudi vedno širše raziskovalne perspektive, ki jo omogoča vedno boljša raziskanost drugih, tudi neslovanskih indoevropskih jezikov. Že samo nova vzporednica znotraj slovanskega leksikona je za nacionalni osamljeni leksem lahko pomemben pokazatelj o njegovem predhistoričnem življenju. Lahko pa taka formalna enačba prispeva k boljšemu razumevanju drugih elementov slovanskega leksikona. Prav to želim pokazati na primeru slovenskega leksema špránja.

\section{Slovensko špránja}

Leksem špránja (f.) 'razpoka (kot dolga ozka odprtina)' je v slovenščini knjižna in narečna beseda. Prvič je bila zapisana razmeroma pozno, šele v 17. stoletju: Shpranîa, shprania, shpranîa 'rima', polhin shprain, inu rafpok 'rimosus', shpranyza 'rimula' (Kastelec-Vorenc), nato v 18. kot shprajna 'Klumfe, rima' (Pohlin) in Shpranja, Shprajna 'Spalt(e)', Shpranja 'Klumse' (Gutsmann). V knjižnem jeziku tvori besedno družino z deminutivom špránjica in pridevnikom špránjast, f. - a 'poln špranj' (SSKJ). V narečjih je bila špránja do sedaj zabeležena v dolenjski narečni bazi (̌̌prá:je (f.) 'špranja' (Šentrupert; Smole 1994: 210)), rovtarski (črnovrško šprâine ‘špranja' (Tominec 1964: 215)) in primorski (nadiško špràn(j)a, sprànja ‘špranja' (Špehonja 2003: 223, 213)). V kostelskem govoru ob šp'ra:n'a 'dolga ozka odprtina v trdi snovi' obstaja tudi deminutiv $\check{s} p^{\prime} r a: n ' e \dot{c} a$ (Gregorič), v Beli krajini pa je bil zabeležen le denominativni glagol

${ }^{2}$ Odgovor na vprašanje, ali je pri Gutsmannu zabeleženo fprienza 'Spalte(e)' [šprienca] $\mathrm{z}$ refleksom ie izvorno dolgega sln. vokala $\bar{e}$ refleks izhodnega špranjica $>\check{\text { sprajnica }>}$ šprejnca $>$ *šprēnca, ostaja še nerešen. 
našpránjiti kaj 'deske, tako naložiti eno vrhu druge, da so vmes špranje' (Šašelj 1906: 276). Koroški rožanski govor pa s špráyha 'špranja' (Šašel 1957: 122) kaže, da je ob špránja obstajala tudi narečna izpeljanka *špránjuga. Gradivo iz različnih narečnih baz kaže na pomensko stabilen leksem, ki je kot geografski termin lahko označeval globoke, tesne ali široke prepoke med skalovjem (Badjura 1953: 173), kot je mogoče sklepati iz imena Špranja v italijanskem delu Julijskih Alp. Samo v treh slovenskih narečnih točkah projekta Slovenski lingvistični atlas, in sicer Trenta, Laniše (pri Škofji Loki) in Rakek, pa je bil za špránja potrjen tudi pomen 'ženski spolni organ', ${ }^{3}$ kar seveda predstavlja pomensko specializacijo iz 'razpoka'.

Dosedanje etimološke obravnave, ki še niso temeljile na vsem omenjenem slovenskem gradivu, so pokazale, da spada leksem med slovenske brez ustreznic v slovanskih jezikih, zato je dolgo časa veljalo Levstikovo prepričanje, da bi bilo leksem treba uvrstiti v plast nemških izposojenk, a je Snoj nakazal, da ima svoje sorodnike v ukr. špára 'razpoka, utor', p. szpara 'razpoka' in č. spára 'reža, razpoka', da bi jo bilo zato treba uvrstiti med člene slovanske besedne družine *pör-ti, *pòr'ešb 'bosti, ločevati, cepiti, parati', prim. r. porótb, pórě̌b 'parati', sln. práti, pọ́rjem/pórjem 'parati, trgati' (Snoj v ESSJ III, s.v. špránja), ${ }^{4}$ češ da je sln. špránja izpeljanka na -nja iz psl. deverbativa *spära, ki se ohranja v omenjenih slov. jezikih, vzglasni $\check{s}$ - oz. $s$ - pa najbrž odražata pide. $s$-mobile (Snoj 1984/85).

Umestitev sln. ̌́pránja v slov. besedno družino *pör-ti 'bosti, ločevati, cepiti, parati', katere člen je tudi iterativ *paräti, je sprejemljiva, vprašanje pa je a) ali vzglasni $\check{s}-\mathrm{v}$ špránja res odraža pide. $s$-mobile, saj ga glagolske oblike te slov. besedne družine obeh prevojnih stopenj (prim. r.-csl. naperi 'prebadati') in tudi edini zanesljivo eksterno soroden gr. glagol $\pi \varepsilon i ́ \rho \omega$ 'prebadati, predirati' (Trautmann 1923: 206; Frisk: II, 492) ne potrjujejo, nimajo pa ga niti nekatere samostalniške oblike, kot npr. sln. razpranje zemlje (n.) 'odprtje zemlje' (Kastelec-Vorenc) ali razpộrek (m.) '(vsaka) podolgovata odprtina, npr. hlačna odprtina' pa hrv. dial. pára (f.) 'zareza' (ARj);

b) ali samostalnik res spada med denominativne tvorbe na -nja tipa *golv-n'ä 'glavno / veliko goreče poleno (v peči)' $\longleftarrow$ *golvä' 'glava', saj med izpeljanko in podstavnim samostalnikom ni mogoče identificirati pomenskih razlik.

Možnost, da bi bilo razmerje med *Spära ${ }^{5}$ in *Spör-n'a le strukturalno zaradi prehoda $\mathrm{v}$ bolj produktivni tip slov. deverbativov pa ni verjetna, ker je

${ }^{3}$ Za podatek se zahvaljujem kolegici dialektologinji Tjaši Jakop.

${ }^{4}$ Ker tudi drugo v nadaljevanju besedila navedeno gradivo govori v prid staroakutiranega glagola *pőr-ti, je poljski nedoločnik próć 'parati, rezati' (standardno pruć 'isto') z znakom za novi akut verjetno tako kot p. wrócić (: hrv. vràtiti, čak. vrōtït) analoški in ima znak za novi akut zaradi vpliva prezentove novoakutirane osnove, tj. psl. *pòr'ešb (prim. sln. pọ́rješ) oziroma *vórtišs (prim. hrv. vrâtīm, čak. vrõtin).

${ }^{5} \mathrm{Z}$ vzglasnim ${ }^{*} S$ - ponazarjam nejasni izvor vzglasnega konzonanta $\mathrm{v} \operatorname{sln}$. špránja, ukr. špára itd. 
stanje v slovanskih jezikih ravno obratno, saj spadajo deverbativi na goli - $a$ tipa *za-bäv-a, *släv-a, *säp-a ... gotovo med najmlajše in najbolj produktivne. Razmerje *Spära : *Spörn'a (= ukr. špára 'razpoka, utor' : sln. špránja) je zato bolj verjetno rezultat dveh različnih deverbativnih vzorcev, pri čemer je *Spära deverbativ iterativa *Sparäti 'bosti, cepiti, rezati, trgati ipd.' še pred terminologizacijo v 'die Naht trennen' (prim. sln. pârati, -am, hrv. párati, pârām, mak. para, p. dial. roz-parać, č. dial. párati), sln. špránja pa deverbativ njegovega besedotvornega predhodnika *Spör-ti in da spada v plast deverbativov tipa $\sin$. próšnja ( $\leftarrow$ prosíti), ki ohranjajo psl. deverbativni tip *pros-nï (f.) 'prošnja' oz. *mbld-nĭ (f.) 'svetlikanje' $\rightarrow$ sln. mólnja (f.) 'puh od strele', hrv. múnja 'strela', čak. mūńä 'isto'. Zaradi verjetne praslovanske starosti sln. špranja pa je možno, da se enak deverbativ ohranja še v katerem drugem slovanskem jeziku.

\subsection{Slovensko špránja : hrvaško špränja}

Širši areal tega psl. deverbativa za sedaj potrjuje le hrvaško gradivo. V kajkavskem Ozlju je namreč znana špränja (f.), ki sicer nima enakega pomena kot slovenska, ampak označuje trsko, enak pomen pa potrjuje tudi njegov denominativ našpränjiti se 'na trsko se nabosti' in zašpränjiti se 'isto' (Težak 1981: 405). Ta kajkavski leksem je bil v istem pomenu zabeležen tudi v Varaždinu: špr'ańa (f.) 'trska' (Lipljin 2002: 1033), v govoru naselja Sveti Đurđ: špr'aĩa 'večja trska' (Belović-Blažeka 2009: 482) in Đurđevac: špränja 'košček lesa, ki se zabode v kožo ali pod noht' (Marešić-Miholek 2001: 702). ${ }^{6}$

Leksem špr'ajna je Slavko Malnar zabeležil na čabranskem območju. V prvi izdaji svojega slovarja ga predstavlja z nevtralnim pomenom 'razpoka v drevesu' in pejorativnim 'deklica' (Malnar 2002: 269), kar je poimenovanje tipa pars pro toto iz pomena 'ženski spolni organ', to pa iz 'razpoka'. S semom razpoka se ta čabranski leksem ujema s slovenskim. Toda v drugi izdaji slovarja leksem pojasnjuje nekoliko drugače: 1. odlomljeni ili puknuti komad drva nastao prilikom obaranja stabla; ${ }^{7} 2$. pogrd. djevojčica; 3. Ženski spolni organ (Malnar 2008: 332). V tej novi predstavitvi pa prvi pomen ni povsem prekriven s slovenskim 'razpoka' in niti s hrvaškim kajkavskim 'trska', ampak izgleda, kot da bi opis realije vseboval tako sém 'trska' (odlomljeni ...) kot tudi sem 'razpoka' (puknuti ...), drugi pa kaže na pomenski razvoj iz prvotnega 'razpoka, podolgovata odprtina'. Tudi v tem se čabaransko območje kaže kot prehodno med arealom s pomenom 'razpoka' in 'trska', kar ne more presenečati, če se vzame v ozir, da govor tudi z drugimi značilnostmi kaže na razvojne poteze, ki so značilne za narečja slovenske jugovzhodne ploskve z refleksom ei za dolgi *ě: in se ga zato upravičeno označuje kot prehodni slovensko-hrvaški govor.

${ }^{6}$ Hrvaški kolegi so me opozorili, da je areal uporabe hrvaške besede špränja 'trska ipd.' širši, češ da presega kajkavsko območje, a ga hrvaški slovarji očitno še niso evidentirali.

${ }^{7} \mathrm{~V}$ slovenskem prevodu 'odlomljen ali počen kos lesa, ki nastane pri podiranju debla'. 
Kakor koli že, slovenski in hrvaški leksem sta formalno identična, glede pomena pa v večini primerov diametralno nasprotna. Pomenska antonimija pa more biti posledica različnosmerne leksikalizacije iz prvotnega deverbativa *Spör-ni 'cepljenje', ko je postal nomen rei acti in je zato lahko označeval razpoke, odprtine, ki so pri cepljenju nastajale, pa tudi trske, iveri, ki so nastale pri istem dejanju. Prav pomenska antonimija nam lahko predstavlja dodatni znak in argument pri utrjevanju, da sln.-hrv. špranja ni denominativna tvorba. Ker je sém 'razpoka/reža' lahko konstitutivni element leksemov za različne druge realije in ker enako velja tudi za sém 'trska', je upravičeno pričakovati, da v to besedno družino spada tudi še kateri drugi slovanski leksem.

\subsection{Hrvaško špranjak}

V hrvaščini bi bilo v to slovensko-hrvaško besedno družino treba uvrstiti samostalnik špránjak (m.), g. špránjka ‘šilasto, rašljasto drvo, kojim se što probada’. $\mathrm{V} \mathrm{ARj} \mathrm{mu} \mathrm{sicer} \mathrm{niti} \mathrm{vir} \mathrm{in} \mathrm{niti} \mathrm{areal} \mathrm{nista} \mathrm{navedena,} \mathrm{tvorjenka} \mathrm{na}-b k b$ pa iz izhodiščnega leksema verjetno ni bila izvedena iz pomena 'trska', kot bi bilo mogoče prehitro sklepati, ampak bolj verjetno iz 'razpoka', ker se s špranjkom prebada in s tem dela razpoke, luknje ipd.

Besedi formalno ustreza v Nemanićevem čakavskem gradivu zabeleženo šprānjàk, g. šprānjkà 'ungula', ki ima ob sebi sinonim šprāljàk, g. šprāljkà 'ungula' (Nemanić 1883: 26). Zanimivo je, da se podobno pomensko razmerje kot pri hrv. špranjak, tj. 'ungula' : 'sredstvo, s čimer se dela razpoke, luknje ipd.' pojavlja tudi pri besedi špraljak, prim. hrv. čak. šprōjäk, g. šprõjka 'kol, s katerim se meče veje v apnenico; lesena igla za pletenje vrste vreč; vrsta majhne šibe' (Brač: Šimunović 2006: 406), v Liki práljak 'lesena palčka, ki se uporablja pri ličkanju; palčka za šivanje vrste klobas; leseno šilo za vleko jermena pri opankah' (Čuljat 2009: 195).
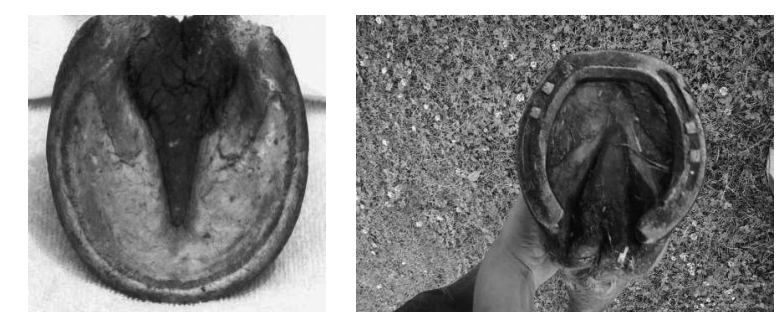

Nepodkovano in podkovano kopito (Pogled s spodnje strani)

Pomen ‘ungula = kopito’ se je v hrv. špránjak in šprāljàk izgleda razvil iz prvotnega 'razpoka'. Povezavo upravičuje tudi realija, saj ima kopito, gledano s spodnje strani, vdrtino trikotnega videza, razpoko, ki jo v slovenščini poimenujemo s strela, kar je lahko kalk n. Strahl am Pferdehufe. Zato ne more biti 
naključje, da enako pomensko motivacijo razpoka $\rightarrow$ kopito najdemo tudi pri že omenjenem p. szpara, starejše spara, ki ob 'podolgovata razpoka, podolgovata ozka odprtina' označuje tudi 'predel med deli kopita ali prsti', kašub. spara, špara pa ob 'podolgovata razpoka' pomeni tudi 'prostor med prsti, zlasti nožnimi'. Ob tem ne bo odveč vedeti, da prostoru med prsti Slovenci rečemo medprstje (Pleteršnik), Nemci pa ga opisujejo s Spalt zwischen Fingern, ki izkazuje enako pomensko motivacijo kot omenjeni primeri.

\subsection{Naglasne razmere: hrv. špránjak : špränja}

Povezavo hrv. špránjak, g. -njka, čak. šprānjàk, g. -njkà s sln. špránja oz. hrv. špränja pa otežuje akcentsko stanje besed, saj sln. in hrv. špranja kažeta na staroakutirano osnovo jslov. *Spörn'-, izpeljanka *Sporn'-b̀kb pa ne. Enako akc. razmerje odraža tudi hrv. čak. präjak 'razcepljeno kopito' (Kastav; ČDL III) < *pörl'akъ/pörl'bkъ ${ }^{8}$ proti omenjenemu Nemanićevemu čak. šprāljàk, g. šprāljkà 'ungula' < *Sporl'b̀kz ${ }^{9}$ ter šprōjäk, g. šprõjka (Brač), práljak (Lika). Slednje razmerje je zanimivo tudi zato, ker sta präjak 'ungula' in práljak brez vzglasnega $\check{s}$-, kar nakazuje, da bi $\check{s}$ - na prvotno vzglasje * $p$ - bil lahko dodan kasneje kot npr. v sln. škrempelj ob krempelj iz srvn. krempel oz. špàrkeu, g. -kla 'parkelj' (Beltinci; Novak 1996) ob sln. párkelj, g. -klja, hrv. kajk. parkalj, g. - klja. $^{10}$ Korenska akutirana intonacija, ki jo odraža nedoločnik *porr-ti = r. porótb, ukr. poróty, br. parócb, se potrjuje tudi v primeru sln. kostelskega p'ra:lèska 'razpoka, špranja' (Gregorič). Samostalnik z unikatnim sln. sufiksom -iska ${ }^{11}$ je enak v 16. st. zabeleženemu praliska (f.) 'razpoka' (Dalmatin, Megiser), tudi v 18. st. pralifka 'Spalte' (Gutsmann), in mora biti izpeljanka *pőrl-iska iz ptc. pret. akt. *pőrlb, ki se ohranja v karpatoukrajinskem pọọ́w, f. poróla k porótı, pọ́r'u, póre 'parati' (Nikolajev-Tolstaja 2001: 150). Ker r. dial. pridevnik póronyj 'razrezan, razparan (o ribjem trebuhu)' (SRNG: 30, 77) < *pôrnz zaradi pide. oksitoniranosti *porH-nó-s tako kot npr. psl. *pôlnъ 'širok, raven, neporaščen' < ${ }^{*}$ polH $_{2}-n o ́-s$ korenskega akuta pričakovano ne potrjuje, je možno, da je na spremembo psl. staroakutiranega deverbativa *Spőr-ni 'cepljenje ipd.' v *Spor-n̋̈, kar je dalo jslov. *Sporn'ä in v nadaljevanju izpeljanko

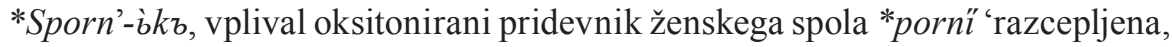
razrezana ipd.’. Razmerje *pörl'akb, *pörliska : *Sporl'b̀kb pa je razložljivo, če $\mathrm{v}$ *pörl'akъ in *pörliska prepoznamo izpeljanke iz psl. ptc. pret. akt. *pörlb,

\footnotetext{
${ }^{8}$ Iz take predloge je po premetu $r a>$ ar lahko nastalo istrsko pàrljak, g. - $a$ 'ungula' (Nemanić 1883: 30).

${ }^{9}$ Izvorni pomen 'razpoka' se lahko ohranja v sln. besedah špralja in špraljica 'odprtina, špranja', ki je bila do sedaj evidentirana le v 17. stoletju v besednjaku Janeza Svetokriškega. Manj je verjetno, da bi bila to izposojenka iz it. spiraglio 'odprtina, reža; žarek' iz lat. spiraculum 'zračna odprtina', kot domneva Snoj v ESSJ IV, 102.

${ }^{10} \mathrm{Hrv}$. beseda je bila zabeležena pri Belostencu in Stuliću in tako poknjižena v ARj.

${ }^{11}$ Gre lahko za feminiziran zahslov. sufiks -isko, nom.-akz.pl. -iska $>\mathrm{f}$.
} 
v *Sporl'b̀k $\leftarrow$ ptc. *pörlb tipa *ôrlb (f.) 'oranje' = sln. râl (f.), g. ralî 'oranje, čas oranja, zorana zemlja' $\leftarrow$ ptc. *örlb k psl. **örti 'orati' = lit. árti 'isto'.

\subsection{Slovensko párkelj, g. -klja in hrvaško kajkavsko parkelj}

Parkelj in kopito sta jezikovno lahko interpretirana kot ena in ista realija, kot npr. ponazarja pomensko polje lat. ungula 'kopito, parkelj', lahko pa je parkelj v odnosu do kopita interpretiran kot razcepljeno kopito, kot ponazarja npr. Pleteršnikova pomenska razlaga der gespaltene Huf slovenskega párkelj. V slovenščini ima beseda párkelj večinoma stabilen pomen in pomeni isto kot n. der gespaltene Huf, toda v rezijanščini 19. stoletja je označevala kopito. ${ }^{12}$ Zato je imel svojčas prav Skok: III, 410, ki je menil, da so Nemanićevi leksemi šprānjàk, g. šprānjkà 'ungula' : šprāljàk, g. šprāljkà 'ungula' : pàrljak, g. -a 'ungula' - dodati bi bilo treba še hrv. čak. präjak 'razcepljeno kopito' - verjetno v neki še nejasni zvezi s hrv. kajk. sinonimom parkelj, g. -klja 'ungula', parkljec 'isto' (Belostenec) in sln. párkelj, g. -klja 'rožena tvorba na koncu prstov nekaterih sesalcev' (SSKJ). ${ }^{13}$

V primerjavi s samo historično znanim kajk. parkelj je sln. leksem dobro znan v narečjih, iz katerih je razvidno, da je korenski del besede staroakutiran (prim. dol. pá:rkel (Šentrupert; Smole 1994: 193), gor. pá:Rkal, g. -na (Kropa; Škofic 1996: 333), pkm. špàrkeu, g. -kla 'parkelj' (Beltinci; Novak 1996) in da sln. zaporedje párk- ne more biti refleks zaporedja *pär-ъk-, ki bi bilo v sln. novocirkumflektirano *pârk-. Zato je sln.-hrv. *pärkъl'b enako kot hrv. čak. pàrljak (: čak. präjak) lahko nastalo po premetu -ra- $\rightarrow$-ar- iz sln.-hrv. *präkbl'b, to pa prav tako po premetu -l'k- $\rightarrow-k l$ '- iz *präl'bkb. Korenski del jslov. *präl-<*pörl- pa je povsem enak tistemu v hrv. čak. präjak 'razcepljeno kopito', tj. 'parkelj'. Sln.-hrv. izoleksa *pärkъl'b 'parkelj' je torej lahko nastala po dveh nesistemskih in zato nepredvidljivih, a tipološko potrjenih jezikovnih pojavih iz jslov. *präl'bkb < *pörl'bkb. Ker sln.-hrv. izoleksa *pärkъl'b vsebuje staroakutiran koren, hrv. šprāljàk = šprōjäk, g. šprõjka, práljak pa ne, je bil tako kot pri hrv. präjak in sln. práliska podlaga za njen nastanek ptc. *pörlı $\rightarrow$ *pörl'bkъ /*pörl'akъ /*pörlisko.

Vzglasni $\check{s}$-, ki se v slovenščini pri leksemu za parkelj pojavlja le v prekmurskem narečju (prim. zgoraj špàrkeu, g. -kla 'parkelj'), v hrv. pa v šprānjàk in $\check{s}$ prāljàk, torej verjetno ni refleks pide. $s$-mobile, na prvotno korensko vzglasje $p$ - pa tudi ni bil dodan šele kasneje, v slovenskem oziroma hrvaškem sistemu.

${ }^{12}$ Podatek za rezijanski pomen je v Pleteršnikovem slovarju naveden iz izgubljenega Cafovega gradiva.

${ }^{13}$ Toda na drugem mestu v slovarju (Skok: II, 609, s.v. parkalj) te možnosti ne omenja. 


\subsection{Slovansko *čsparъ < *čb-parъ}

Primerljivo pomensko variabilnost 'trska' : 'razpoka' > 'kopito/parkelj' kot zgornji izrazi imajo tudi refleksi psl. samostalnika *čsparı. To so nedvomno srb. čpâr, g. - $a$ 'na drvetu nešto kao trn, zalomljena grana na što se čovek može nabosti i povrediti' $\mathrm{z}$ denominativom načpārït se, načpârim se 'nabosti se na čpar, okrljak' (Kosovo; Elezović 1932-1935: 1, 455), ${ }^{14}$ ki glede pomena ustreza hrv. dial. špränja 'trska'. Pomensko bolj oddaljeno hrv. dial. čpâr 'oster, koničast kamen' (Popović 1960: 539), ${ }^{15}$ č. v mesarskem slengu uporabljano čpár in špár 'krempelj, parkelj, noga' (Jungmann I, 310), tudi čpárka 'kozji parkelj' pa je tako kot stsrb. čbparoga 'ungula' (Daničić) in srb.-csl. čbparogъ 'ungula' pomensko prekrivno s hrv. čak. šprānjàk 'ungula', šprāljàk 'isto', präjak 'razcepljeno kopito' idr.

Ker se vzglasni $*_{c}$ - po izpadu polglasnika ob stiku z zapornikom fonetično poenostavi v $\check{S}$-, je razumljivo, da se iz *čbparb oz. besedotvorne variante *čspara izvaja tudi slovansko gradivo z vzglasjem $\check{s} p$-, kot je npr. dl. dial. špara 'krempelj, parkelj', gl. špara 'krempelj' ali p. szpara 'podolgovata razpoka, podolgovata ozka odprtina; predel med deli kopita ali prsti', kašub. špara 'podolgovata razpoka; prostor med prsti, zlasti nožnimi' (Berneker 1908-1913: 169; Popović 1960: 1.c.; Machek 1968: 107; SP: 2, 314; Boryś 2005: 605).

Čeprav je izvajanje refleksov z vzglasjem $\check{s} p$ - iz izhodišča *čsparz oz. *čbpara fonetično sprejemljivo, je enako možno, da bi vzglasje $\check{s} p$ - v posameznih slov. jezikih paralelno nastalo iz vzglasij $s p$ - samostalnikov s podobnim ali enakim pomenom, kot so č. spár 'krempelj, parkelj', spárek 'krempeljček', tudi spára 'reža, razpoka, praska, špranja', dl. spara 'razpoka na pragu', gl. spara 'parkelj', stp. spara 'razklan les', p. dial. spara 'predel med deli kopita ali prsti', ukr. spára 'razpoka'. Ta njihova karakteristika jih uvršča v besedno družino *pör- $t i$ 'parati', saj so lahko deverbativi psl. perfektiviziranega iterativa *sb-parati 'razcepiti, razrezati, razparati ipd.'.

Variantno izglasje $\check{c} p-: \check{s} p-: s p$ - je pri tem pomensko primerljivem gradivu verjetno posledica medsebojnega vpliva izhodnih leksemov *čbparb oz. *čbpara in *szparb oz. *szpara. Celo trojni sinonimni refleksi, kot jih izkazuje češko razmerje čpár : špár : spár, pa ne govorijo v prid možnosti, da bi psl. *čbparb popolnoma ločili od psl. besedne družine *pőr-ti 'parati' in ga morda morfemizirali drugače, npr. $\mathrm{v} *{ }^{*}$ b $p a-r ъ$ ter $\mathrm{v}$ njem prepoznali nomen actionis tipa gl. spar 'spanje' < *sbpa-rb k *sъpa-ti 'dormire'16 nikjer potrjenega ničtokorenskega glagola *čbpa-ti 'cepiti', sorodnega s *cěpiti 'klati, sekati'. Bolj je namreč

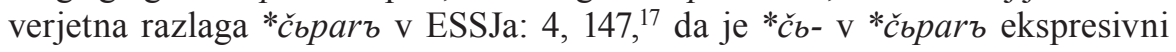

\footnotetext{
${ }^{14}$ Srb. očpárak 'štor vitkega drevesa; oster kos lesa' (južna Srbija; citirano po Bjeletić 2006: 318) je deverbativ iz denominativnega glagola $*$ ob-čbpar-iti $\leftarrow *^{*} c ̌ b p a r b$.

${ }^{15} \mathrm{~K}$ temu denominativ načparit se 'ubosti se' (Popović 1960: 1.c.).

${ }^{16}$ Več o tem samostalniku Furlan v ESSJ: III, 296, s.v. spáti.

${ }^{17}$ Prej že Holub - Kopečný 1952: 346.
} 
prefiks, ki se v slov. jezikih pojavlja tudi v variantah $* \check{c} e-$ in $* k o-,{ }^{18}$ in da je treba *-parz povezati z besedno družino *pör-ti 'parati'. Razlaga o obstoju psl. ekspresiviziranega glagola *čb-pőr-ti ob *pőr-ti in njegova iterativa *čb-parät $i$ ob *paräti se zdi bolj verjetna tudi, ker vzglasja $\check{c} p$ - nimajo le samostalniki, ampak tudi glagol, kot je še vidno v mak. dial. čpara 'rezati'. ${ }^{19}$

\subsection{Psl. *pőr-ti $\rightarrow{ }^{*}$ čb-pőr-ti}

Tako kot pri drugih sicer redkih zanesljivih primerih, kjer se pojavlja eden od prefiksov *čb-: *če- : *ko- (prim. *če-pelz-ti ${ }^{20}$ ob *pelz-ti; *ko-muditi ob *muditi, *ko-mъrdati ob *mъrdati ...), so tudi v tej besedni družini pomenske razlike med členi s prefiksom *čb- in brez njega tudi z aplikacijo komparativne metode danes neprepoznavne, npr. č. čpár/ špár : spár, vse v pomenu 'krempelj, parkelj', hrv. šprāljàk : präjak / pàrljak, vse v pomenu 'ungula', sln. špàrkeu : párkelj (= hrv. parkelj), vse v pomenu 'ungula'. Kar je iz gradiva mogoče razpoznati, je le to, da je v psl. ob glagolu *pör-ti s pomenskim poljem 'bosti, ločevati, cepiti, parati' moral obstajati tudi prefigiran *̌cb-pőr-ti in da se soobstoj psl. glagolskih osnov *pör- in *čb-pör-posredno potrjuje tudi v glagolskih (npr. mak. čpara : sln. párati) in imenskih izpeljankah (npr. sln. špàrkeu : párkelj; hrv. šprāljàk: sln. praliska), ki iz njiju posredno ali neposredno izvirajo.

Sln.-hrv. špranja $<$ jslov. *čb-pörn'a $<$ psl. *čb-pörni more torej biti deverbativ psl. prefigiranega *čb-pőr-ti 'bosti, ločevati, cepiti', pri čemer je do dvosmernega razvoja v pomen 'razpoka ipd.' in v 'trska' lahko prišlo šele, ko je prišlo do konkretizacije glagolskega dejanja v rezultat.

\section{Dvosmerne leksikalizacije: soobstoj pomenov 'trska' in 'razpoka'}

Jslov. *čb-pörn'a > sln. špránja 'razpoka', hrv. špränja 'trska' je torej enako pomensko motivirano kot arealno širše *skäla ( $\leftarrow$ * skäliti 'cepiti'), kjer pomen 'trska' potrjuje slovensko, hrvaško, ukrajinsko in poljsko gradivo, leksikalni pomeni 'petra' ali 'saxum' pa predstavljajo drugačen rezultat zaradi drugačne snovi cepljenja. Pomen 'razpoka ipd.' pa je bil do sedaj prepoznan le v dl.

${ }^{18}$ Zaradi alternacije $* \check{c} b-: * \check{c} e-: * k o$ - bi bilo mogoče pritrditi teoriji, da gre tu za prefikse, ki so po izvoru pronominalne osnove. O tem več Bjeletić 2006: 378, z literaturo. Jezikoslovna oznaka 'ekspresivni prefiks' je pri tovrstnih slov. prefiksih zasilna in morda tudi neustrezna, saj iz razmerij z in brez 'ekspresivnega prefiksa' praviloma ni mogoče prepoznati niti funkcijske (nevtralno : ekspresivno) niti pomenske razlike. Upoštevajoč to dejstvo, bi bilo morda bolje govoriti o slov. strukturalnih prefiksih, tj. o funkcionalno in pomensko izpraznjenih prefiksih.

19 Citirano po ESSJa: 4, 148.

${ }^{20}$ Od tod je jslov. ftn *če-pelzъ (m.) 'Asphodelus', ki se kot apelativ ali pa onimiziran potrjuje le v sln., hrv. in mak. (Furlan 2008: 13s, s starejšo literaturo). 
skała 'soteska, razpoka, votlina' poleg 'skala'. Enako pomensko razmerje je razpoznavno tudi iz leksikalnih pomenov psl. * *̌čeps ( $\leftarrow$ psl. *ščep-ti, prim. br. ščepácb 'cepiti'), prim. sln. ščëp, g. ščépa 'trska, iver' : gl. šćép 'razpoka'.

$\mathrm{V}$ kontekstu takih dvosmernih leksikalizacij bivših nomenov actionis bi bilo treba razumeti tudi pomene $\mathrm{v}$ blg. iver, ki poleg 'iver' pomeni tudi 'jamica $\mathrm{v}$ kamnu, kjer se nabira voda', iverb pa 'podolgovata zareza', ${ }^{21}$ čemur je treba dodati tudi srb. ivóra 'lijakasta vdolbina v steni, ker se nabira voda'. Čeprav je v BER: 2, 4, pomensko razmerje 'iver' : 'vdolbina v kamnu' pri blg. ìver označeno kot nejasno in je Loma 2006: $229 \mathrm{~s} .{ }^{22} \mathrm{v}$ takem pomenskem razmerju videl sovpad genetično različnih homonimov, je iz že naštetih primerov razvidno, da imamo tudi pri tem slovanskem leksemu opravka z dvosmerno leksikalizacijo rezultativnega nomena actionis.

\section{VIRI IN LITERATURA}

ARj: Rječnik hrvatskoga ili srpskoga jezika. Zagreb: Jugoslavenska Akademija znanosti i umjetnosti. 1880-1976.

Rudolf BADJURA, 1953: Ljudska geografija. Terensko izrazoslovje. Ljubljana: Državna založba Slovenije.

Stjepan BELOVIĆ, Đuro BLAŽEKA, 2009: Rječnik govora svetog Đurđa (Rječnik ludbreške Podravine). Zagreb: Učiteljski fakultet.

BER: Bъlgarski etimologičen rečnik I-. Sofija: Bъlgarska akademija na naukite. 1971-.

Erich BERNEKER, 1908-1913: Slavisches etymologisches Wörterbuch. Erster Band. Heidelberg: Carl Winter's Universitätsbuchhandlung.

Marta BJELETIĆ, 2006: Iskovrnuti glagoli. Beograd: Institut za srpski jezik SANU.

Wiesław BORYŚ, 2005: Stownik etymologiczny języka polskiego. Kraków: Wydawnictwo literackie.

ČDL: Čakavisch-deutsches Lexikon I-III. Köln - Wien: Böhlau Verlag. 1979-1983.

Marko ČULJAT, 2009: Ričnik ličke ikavice. Gospić: Lika press.

G1. ELEZOVIĆ, 1932-1935: Rečnik kosovsko-metohijskog dijalekta I-II. Beograd: Grafički umetnički zavod Planeta.

${ }^{21}$ Od tod izpeljanke iverka 'jamica $\mathrm{v}$ skali, kjer se nabira deževnica', tudi ivorka 'čista voda, ki se je nabrala v skali, drevesu ipd.', iverec 'isto'.

${ }^{22} \mathrm{~V}$ članku avtor besedotvorni problem tega slov. leksema, ki se ga navadno izvaja iz deverbativa $*_{j b-v e r}$ z nejasnim morfemom * $j_{b-}$, elegantno rešuje z izvajanjem iz prvotnega deverbativa *vy-vers (zaradi blg. in srb. gradiva tudi *vy"-vorz), v katerem je delovala disimilacija $v: v \rightarrow j: v$ tipa srb. jëverica 'veverica' (Vuk) <*vĕ́verica 'sciurus', nato pa

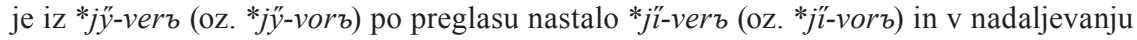
*i-vers (oz. *i-vorz). 
ESSJ: France Bezlaj, 1976-2007: Etimološki slovar slovenskega jezika I-V. Avtorji gesel France Bezlaj, Marko Snoj in Metka Furlan. Ljubljana: Mladinska knjiga + Založba ZRC.

ESSJa: Ètimologičeskij slovar' slavjanskich jazykov 1-. Moskva: Nauka. 1974-.

Hjalmar FRISK, 1973: Griechisches etymologisches Wörterbuch I-II. Zweite, unveränderte Auflage. Heidelberg: Carl Winter Universitätsverlag.

Metka FURLAN, 2008: Eksterna in interna rekonstrukcija v slovanski etimologiji -Slavistična revija 56/2 = Zbornik referatov za štirinajsti mednarodni slavistični kongres Ohrid, 10.-17. september 2008, 3-16.

GREGORIČ: Gradivo za kostelski slovar. Računalniška datoteka.

Oswald GUTSMANN, 1789: Deutsch-windisches Wörtebuch mit einer Sammlung der verdeutschten windischen Stammwörter, und einer vorzüglichern abstammenden Wörter. Verfasset von Oswald Gutsmann. Klagenfurt.

Josef HOLUB- František KOPEČNÝ, 1952: Etymologický slovník jazyka českého. Praha: Státní nakladatelství učebnic v Praze.

Joseph JUNGMANN, 1989: Slovnik česko-německý I-V (Praha 1835-1839). Praha: Academia.

Matija KASTELEC-Gregor VORENC: 1997: Slovensko-latinski slovar. Po: Matija Kastelec - Gregor Vorenc, Dictionarium Latino-Carniolicum (1680-1710). Ljubljana: Založba ZRC.

Tomislav LIPLJIN, 2002: Rječnik varaždinskoga kajkavskog govora. Varaždin: Garestin.

Aleksandar LOMA, 2006: O jednom istočnosrbijansko-zapadnobugarskom dialektizmu (srp. dijal. ivora, bug. dijal. iver i sl.) - Godišnjak za srpski jezik i književnost Filološkog fakulteta u Nišu 20/8, 220-233.

Václav MACHEK, 1968: Etymologický slovnik jazyka českého. Druhé, opravené a doplněné vydání. Praha: Nakladatelství Československé akademie věd.

Slavko MALNAR, 2002: Pamejnek. Govor u čabarskom kraju. Čabar - Rijeka: Matica Hrvatska Čabar.

Slavko MALNAR, 2008: Rječnik govora čabarskog kraja. Čabar: Matica hrvatska. Ogranak Čabar.

Jela MAREŠIĆ-Vladimir MIHOLEK, 2011: Opis i rječnik đurđevačkoga govora. Đurđevac: Gradska knjižnica Đurđevac.

D. NEMANIĆ, 1883: Čakavisch-kroatische Studien. Erste Studie. Accentlehre. Wien: In Commission bei Carl Gerold'e Sohn.

S. L. NIKOLAJEV-M. N. TOLSTAJA, 2001: Slovarb karpatoukrainskogo torunbskogo govora s grammatičeskim očerkom i obrazcami tekstov. Moskva: Rossijskaja akademia nauk.

Franc NOVAK, 1996: Slovar beltinskega prekmurskega govora. Drugo, popravljeno in dopolnjeno izdajo priredil in uredil Vilko Novak. Murska Sobota: Pomurska založba.

Maks PLETERŠNIK, 2006: Slovensko-nemški slovar 1894-1895. Elektronsko izdajo iz leta 2006 uredile M. Furlan, H. Dobrovoljc in H. Jazbec. Ljubljana: Založba ZRC. 
Marko POHLIN, 1972: Tu malu besedishe treh jesikov 1781. Faksimile prve izdaje. München: Dr. Dr. Rudolf Trofenik.

Ivan POPOVIĆ, 1960: Geschichte der serbokroatischen Sprache. Wiesbaden: Otto Harrassowitz.

Hans SCHUSTER-ŠEWC, 1983-1989: Historisch-etymologisches Wörterbuch der oberund niedersorbischen Sprache. Bautzen: Veb Domowina-Verlag.

Petar SKOK, 1971-74: Etimologijski rječnik hrvatskoga ili srpskoga jezika I-IV. Zagreb: Jugoslavenska Akademija znanosti i umjetnosti.

Vera SMOLE, 1994: Oblikoglasje in oblikoslovje šentruperskega govora. Disertacija. Univerza v Ljubljani. Ljubljana.

Marko SNOJ, 1984/85: Dve etimologiji - Jezik in slovstvo 30, 117-120.

SP: Słownik prastowiański I-. Wrocław - Warszawa-Kraków - Gdańsk: Wydawnictwo Polskej Akademii nauk. 1974-.

SRNG: Slovarb russkich narodnych govorov 1-. Leningrad: Izdatelıstvo Nauka. 1965-.

SSKJ: Slovar slovenskega knjižnega jezika I-V. Ljubljana: Državna založba Slovenije. 1970-1991.

Joakim STULIĆ, 1985: Joakima Stulli Dubrocsanina svechenika reda S. Franceska Serafinskoga Rjecsosloxje I-II. U Dubrovniku 1806 (Reprint and Afterword by E. Fekete. München: Verlag Otto Sagner).

Josip ŠAŠEL, 1957: Rožanski narečni besednjak. Rokopis. Hrani Inštitut za slovenski jezik Frana Ramovša ZRC SAZU v Ljubljani.

Ivan ŠAŠELJ, 1906-1909: Bisernice iz belokranjskega narodnega zaklada I-II. V Adlešičih nabral Ivan Šašelj. Ljubljana.

Petar ŠIMUNOVIĆ, 2006: Rječnik bračkih čakavskih govora. Supetar: Brevijar.

Jožica ŠKOFIC, 1996: Glasoslovje, oblikoslovje in besedišče govora Krope na Gorenjskem. Disertacija. Univerza v Ljubljani. Ljubljana.

Nino ŠPEHONJA, 2003: Vocabolario del Nadiško. Uporabljana je bila inačica slovarja, ki je bila na: http://www.lintver.it/pdf/vocabolario_natisoniano-italiano.pdf dostopna $\mathrm{v}$ letu 2003.

Stjepko TEŽAK, 1981: Ozaljski govor - Hrvatski dialektološki zbornik V, 203-427.

Ivan TOMINEC, 1964: Črnovrški dialekt. Kratka monografija in slovar. Ljubljana: Slovenska akademija znanosti in umetnosti.

Reinhold TRAUTMANN, 1923: Baltisch-Slavisches Wörterbuch. Göttingen: Vandenhoeck \& Ruprecht.

Maks VASMER, 1986-1987: Fasmer, Ėtimologičeskij slovarb russkogo jazyka I-IV. Perevod s nemeckogo i dopolnenija člena-korrespondenta AN SSSR O. N. Trubačeva. Izdanie vtoroe, stereotipnoe. Moskva: Progres. 


\section{SLOVENIAN ŠPRANJA AND RELATED}

Alongside PSl. *pőr-ti ‘rip' (= Rus. porótb, pórešb ‘rip', Sln. práti, pọ́rjem/pórjem 'rip, tear') there must have also existed the synonymous prefixed verb *čb-pör-ti, which was the base for the formation of the nomen actionis of the type Sln. prošnja $\leftarrow$ prositi; i.e., PSl. *čb-pör-ni 'splitting; that which results from splitting: crack / wood chip', which is preserved in Sln. špránja 'crack' and Cro. špränja 'wood chip'.

Because the meaning 'crack' can specialize into the denotation for a solid hoof, which has a crack = cleft of triangular appearance in the back, and because a solid hoof and a cloven hoof can easily be linguistically interpreted as one and the same thing (cf. the meaning of Lat. ungula), the same Slavic word family *pör-ti 'rip' also includes Cro. šprānjàk, gen. šprānjkà 'ungula' (alongside Cro. špránjak (m.), gen. špránjka 'pointed, forked tree that something pierces') and šprāljàk, gen. šprāljkà 'ungula' (alongside $\check{s}$ prōjäk, gen. šprõjka 'pole used to throw branches into a lime kiln; wooden needle for knitting a kind of bag ...'), and the accentual deviation can be explained by the influence of the adjective *pôrn s (= Rus. dial. póronyj 'sliced open, ripped open (of a fish stomach)') and the existence of the substantive *porlb (f.) 'splitting' from the ptcp. *pörlb (= Ukr. dial. porọ́w, f. poróla), which is also preserved in Sln. práliska 'crack', Cro. Čak. präjak 'cloven hoof', and further in the Sln.-Cro. isolexeme *pärkbl'b 'cloven hoof' (which could have arisen through double metathesis from South Sl. *präl'bkъ < *pörl'bkr).

The same PSl. verb * čb-pör-ti was the base for the iterative (cf. Mac. čpara 'cut'), from which are the deverbals in Cz. čpár 'claw, cloven hoof, leg', Old Serb. čbparoga 'ungula', SCr. čbparog ‘ 'ungula' (alongside Serb. čpâr, gen. - $a$ 'something like a thorn on a tree, a broken branch that a person can poke against and be hurt').

Bidirectional lexicalization, which is expressed at synchronic levels in the form of antonymy (Sln. špránja 'crack' : Cro. špränja 'wood chip'), can also be expected in other resultative nomina actionis; e.g., *skäla $\leftarrow$ *skäliti 'split': LSorb. skała 'gorge, crevasse, cavern' alongside 'cliff'; *ščeps $\leftarrow$ PSl. *ščep-ti: Sln. ščëp, gen. ščépa 'wood chip, splinter', USorb. šćép 'crack'; Blg. iver 'splinter', 'cavity in a rock where water collects'. 